\title{
UJI EFEK DIURETIK EKSTRAK DAUN ALPUKAT (Persea americana Mill) PADA TIKUS PUTIH (Rattus norvegicus)
}

\section{Test of Diuretic Effects of Avocado Leaf (Persea americana Mill) Extract in White Rats (Rattus norvegicus)"}

\author{
Meliana Novitasari ${ }^{1}$, Kiki Puspitasary ${ }^{2}$ \\ STIKES Mamba'ul 'Ulum Surakarta \\ meliananovitasari26@gmail.com
}

\begin{abstract}
ABSTRAK
Latar Belakang: Diuretik ialah obat yang dapat meningkatkan kecepatan aliran urin dan ekskresi natrium dan klorida $(\mathrm{NaCl})$. Istilah diuresis mempunyai dua pengertian, pertama menunjukan adanya penambahan volume urin yang diproduksi dan yang kedua menunjukan jumlah pengeluaran (kehilangan) zat-zat terlarut dan air. Penggunaan klinis diuretika yang paling penting adalah untuk edema dengan jalan mengeluarkan cairan edema (elektrolit), sehingga cairan ekstraseluler kembali normal

Tujuan penelitian: Untuk mengetahui efek diuretik ekstrak daun alpukat (Persea americana Mill) pada hewan uji Tikus Putih(Rattus norvegicus)".

Metode:Desain penelitian yang digunakan adalah eksperimental laboratorium yang di laksanakan di Laboratorium Farmakologi S1 Farmasi STIKES Mamba'ul U'lum surakarta.Penelitian ini menggunakan 15 ekor mencit yang di bagi menjadi 5 kelompok yang terdiri atas kelompok I sebagai kontrol negatif dengan pemberian suspensi Na.CMC $1 \%$ b/v, kelompok II, III, IV sebagai kelompok perlakuan yang di berikan ekstrak daun alpukatmasing-masing sebesar $1 \% \mathrm{~b} / \mathrm{v}$, $2 \% \mathrm{~b} / \mathrm{v}$, dan $3 \% \mathrm{~b} / \mathrm{v}$. Pengamatan volume urin selama 5 jam dilakukan setelah perlakuan.

Hasil: Penelitian menujukkan pemberian ekstrak daun alpukat dengan konsentrasi $3 \% \mathrm{~b} / \mathrm{v}$ menunjukan efek paling baik sebagai diuretik terhadap tikus putih, tetapi pemberian suspensi furosemid $0,072 \% \mathrm{~b} / \mathrm{v}$ masih memiliki efek yang lebih baik sebagai diuretik.

Simpulan: Pemberian ekstrak daun alpukatpada konsentrasi3\% b/v menunjukajukan efek paling baik sebagai diuretik terhadap tikus putih, tetapi pemberian suspensi furosemid $0,072 \% \mathrm{~b} / \mathrm{v}$ masih memiliki efek yang lebih baik sebagai diuretik
\end{abstract}

Kata Kunci: Ekstrak, Daun Alpukat, Diuretik

\section{ABSTRACT}

Background:Diuretics are drugs that can increase the rate of urine flow and the excretion of sodium and chloride $(\mathrm{NaCl})$. The term diuresis has two meanings, the first indicates an increase in the volume of urine produced and the second 
indicates the amount of excretion (loss) of solutes and water. The most important clinical use of diuretics is for edema by removing edema fluid (electrolytes), so that the extracellular fluid returns to normal.

Research purposes: The study aims to find out the diuretic effect of avocado leaf extract (Persea americana Mill.) in a white mouse test animal (Rattus norvegicus).

Methods:The research design used was experimental laboratory which was carried out in the Pharmacology Laboratory of S1 Pharmacy STIKES Mamba'ul U'lum, Surakarta. This study used 15 mice which were divided into 5 groups consisting of group I as negative control by giving $1 \% \mathrm{w} / \mathrm{v} N \mathrm{Na}$.CMC suspension, groups II, III, IV as treatment groups which were given each avocado leaf extract. at $1 \% \mathrm{w} / v, 2 \% \mathrm{w} / \mathrm{v}$, and $3 \% \mathrm{w} / \mathrm{v}$. Observation of urine volume for 5 hours was carried out after treatment.

Results:The results of the study indicated that the introduction of avocado leaves with a concentration of $3 \% \mathrm{~b} / \mathrm{v}$ showed the best effect as a diuretic against white rats, but the administration of furosemide suspension $0.072 \% \mathrm{~b} / \mathrm{V}$ still had a better effect as a diuretic.

Conclusion: The administration of avocado leaf extract at a concentration of $3 \%$ $w / v$ showed the best effect as a diuretic against white rats, but giving frusemide suspension $0.072 \% \mathrm{w} / \mathrm{v}$ still had a better effect as a diuretic.

Key Words: Extract, Avocado Leaf, Diuretic

\section{PENDAHULUAN}

Diuretik ialah obat yang dapat meningkatkan kecepatan aliran urin dan ekskresi natrium dan klorida $(\mathrm{NaCl})$. Istilah diuresis mempunyai dua pengertian, pertama menunjukan adanya penambahan volume urin yang diproduksi dan yang kedua menunjukan jumlah pengeluaran (kehilangan) zat-zat terlarut dan air (Gunawan, G.S, 2016). Penggunaan klinis diuretika yang paling penting adalah untuk edema dengan jalan mengeluarkan cairan edema (elektrolit), sehingga cairan ekstraseluler kembali normal (S. Elin, 2015). Diuretika digunakan pada semua keadaan dimana dikehendaki peningkatan pengeluaran air, khususnya pada hipertensi dan gagal jantung (Tjay, T. H, dan Rahardjo, K,2010).

Pengeluaran urin yang tidak lancar memicu timbulnya penyakit dalam tubuh, penyakit yang sering muncul akibat pengeluaran urin yang tidak lancaradalah batu ginjal. Salah satu cara menyembuhkan batu ginjal adalah meningkatkan laju pengeluaran urin dengan penggunaan senyawa yang bersifat diuretik. Diuretik merupakan suatu senyawa yang dapat meningkatkan laju pengeluaran volume urin dan meningkatkan eksresi bahan terlarut dalam urin seperti ion natrium dan klorida (Gunawan, G.S, 2016).

Masyarakat Indonesia telah mengenal berbagai jenis tanaman obat dan memanfaatkannya untuk menjaga kesehatan dan pengobatan berbagai penyakit. 
Pengobatan tersebut kebanyakan diperoleh berdasarkan pengetahuan masyarakat secara turun-temurun, namun sebagian besar tanaman obat yang ada belum dapat dibuktikan secara ilmiah (Latuconsina. N. H., dkk, 2014).

Saat ini minat masyarakat terhadap pengobatan dengan obat alam semakin meningkat. Pemanfaatan tanaman baik sebagai obat maupun tujuan lain merupakan salah satu fenomena yang terjadi saat ini. Banyak masyarakat Indonesia yang mempercayakan pengobatan tradisional dari pada pengobatan modern, dikarenakan lebih minim efek samping yang ditimbulkan oleh penggunaan obat tradisional (Sudradjat, A., dan Aan, 2017).

Tanaman alpukat merupakan salah satu tanaman yang memiliki manfaat sebagai obat tradisional. Daun alpukat merupakan salah satu bahan alami yang dapat digunakan sebagai obat tradisional. Daun ini secara empiris dipercaya sebagai diuretik yaitu menambah volume urin yang dihasilkan saat urinasi (Yuniarti, 2008).

Persea gratissima Gaertn. Sinonim: Persea americana merupakan tanaman yang berasal dari Amerika Tengah. Buah dan daun mengandung saponin, alkaloid, dan flavonoid(AgroMedia Redaksi, 2008).

Penelitian sebelumnya mengenai diuretik dengan menggunakan ekstrak daun alpukat (Persea americana Mill.) telah dilakukan oleh Erlinda (2017) dengan dosis $50 \mathrm{mg} / \mathrm{kgBB} ; 100 \mathrm{mg} / \mathrm{kgBB} ; 150 \mathrm{mg} / \mathrm{kgBB}$. Dimana dosis $150 \mathrm{mg} / \mathrm{kgBB}$ memiliki efek diuretik paling baik dari dosis yang lainnya.

Oleh karena itu, perlu dilakukan penelitian yang bertujuan untuk mengetahui efek diuretik ekstrak daun alpukat sebagai diuretik alami terhadap hewan uji tikus putih (Rattus novergicus).

\section{METODE PENELITIAN}

Jenis penelitian yang dipakai dalam penelitian ini adalah penelitian eksperimental, yang merupakan penelitiandengan menggunakan bahan uji daun alpukat (Persea americana Mill).Variabel ini menggunakan variabel bebas penelitian yang digunakan adalah eksperimental yang dilaksanakan di Laboratorium Farmakologi S1 Farmasi Stikes Mamba'ul 'Ulum Surakarta. Variabel ini menggunakan variabel terikat yaitu menggunakan daun alpukat (Persea americana Mill) pada hewan uji tikus puth (Rattus norvegicus), yang sehat dengan bobot badan 100-200 gram. Jumlah tikus yang digunakan adalah 15 ekor yang dibagi dalam 5 kelompok, setiap kelompok terdiri dari 3 ekor tikus.

Metode yang di gunakan yaitu Daun alpukat (Persea americana Mill.) yangdigunakan adalah daun alpukat (Persea americana Mill.) yang masih segar diambil dari Kebun tanaman Alpukat di daerah Karanganyar. Daun alpukat (Persea americana Mill.) dicuci dengan air mengalir sampai bersih lalu ditiriskan dan ditimbang, selanjutnyadipotong-potong kecil kemudian dikeringkan dengan cara diangin-anginkan dan ditimbang, lalu dibuat menjadi serbuk kemudian diayak dengan ayakan nomor 40. Serbuk yang tidak terayak dihaluskan lagi sampai serbuk terayak. Setelah itu serbuk ditimbang dan selanjutnya dibuat ekstrak. 
Setelah semua Tikus putih jantan mendapat perlakuan,kemudian diamati dan dicatat data meliputi volume urin selama 5 jam setelah perlakuan. Selanjutnya setelah selesai, melakukan pengolahan analisis data menggunakan tabel dan grafik.Hasil data yang diperoleh dianalisis dengan menggunakan uji statistik Anova dan Uji lanjutan Newman Keuls untuk diambil suatu kesimpulan.

\section{HASIL DAN PEMBAHASAN}

\section{Hasil}

Setelah melakukan pengamatan mengenai uji efek diuretik ekstrak etanol daun alpukat (Persea americana Mill.) pada tikus putih (Rattus norvegicus) diperoleh hasil sebagai berikut :

Tabel 1. Hasil Pengamatan Volume Urin (mL) Yang Dihasilkan setelah Perlakuan Terhadap Tikus Putih Selama 5 Jam.

Replikas
1
2
3
$\Sigma$
$\mathbf{X}$

I
2,5
1
1
4,5
1,5

$\begin{array}{cc} & \text { Volume Urin (mL) } \\ \text { II } & \text { III } \\ 2 & 2,5 \\ 2,1 & 2 \\ 1,8 & 2,1 \\ 5,9 & 6,6 \\ 1,97 & 2,2\end{array}$

IV
4
4
5
13
4,3

$\begin{array}{cc}\text { V } & \begin{array}{c}\text { Jumlah } \\ \text { Total }\end{array} \\ 5,3 & 16,3 \\ 5,5 & 14,6 \\ 6 & 15,9 \\ 16,8 & 46,8 \\ 5,6 & \end{array}$

Keterangan :

$$
\begin{array}{ll}
\Sigma & \text { : Jumlah Volume urin }(\mathrm{mL}) \\
\mathrm{X} & \text { : Rata-rata Volume urin }(\mathrm{mL}) \\
\mathrm{I} & \text { : Suspensi Na.CMC } 1 \% \mathrm{~b} / \mathrm{v} \text { (Kontrol negatif) } \\
\mathrm{II} & \text { : Ekstrak etanol daun alpukat } 1 \% \mathrm{~b} / \mathrm{v} \\
\mathrm{III} & \text { : Ekstrak etanol daun alpukat } 2 \% \mathrm{~b} / \mathrm{v} \\
\mathrm{IV} & \text { : Ekstrak etanol daun alpukat } 3 \% \mathrm{~b} / \mathrm{v} \\
\mathrm{V} & \text { : Suspensi Furosemid } 0,072 \% \mathrm{~b} / \mathrm{v} \text { (Kontrol positif) }
\end{array}
$$

\section{Pembahasan}

Diuretik ialah obat yang dapat meningkatkan kecepatan aliran urin dan ekskresi natrium dan klorida $(\mathrm{NaCl})$. Istilah diuresis mempunyai dua pengertian, pertama menunjukan adanya penambahan volume urin yang diproduksi dan yang kedua menunjukan jumlah pengeluaran (kehilangan) zat-zat terlarut dan air (Erlinda, Dwi. 2017).

Pada penelitian uji efek diuretik ekstrak etanol daun alpukat (Persea americana Mill.) pada tikus putih (Rattus norvegicus) menggunakan satu variabel yaitu volume urin. Volume urin di tampung dalam gelas ukur dan diukur setiap kali tikus putih jantan mengeluarkan urin, kemudian volume urin dijumlah setelah 5 jam (Febrianti dkk, 2016).

Sebelum perlakuan, masing-masing tikus putih jantan dipuasakan selama 12-18 jam. Hal ini dimaksudkan untuk menghindari kemungkinan adanya 
pengaruh makanan terhadap kandungan bahan berkhasiattumbuhan ekstrak etanol daun alpikat yang dapat mempengaruhi efek diuretik yang ditimbulkan.

Penelitian ini menggunakan furosemida sebagai pembanding dengan maksud untuk membandingkan efek diuretik dari beberapa konsentrasiekstrak etanol daun alpukat. Furosemida digunakan sebagai pembanding karena jenis obat ini banyak digunakan sebagai obat diuretik. Furosemid merupakan derivat sulfonamida yang berdaya diuretik kuat dengan mulai kerja 0,5-1 jam dan bertahan selama 4-6 jam yang ekskresinya melalui urin.

Berdasarkan hasil penelitian menunjukkan bahwa pada pemberian ekstrak etanol daun alpukat untuk pengamatan jumlah volume urin menunjukkan bahwa pemberian Na. CMC $1 \% \mathrm{~b} / \mathrm{v}$ sebagai kontrol negatif memperlihatkan volume urinrata-rata sebesar $1,5 \mathrm{~mL}$, pemberian ekstrak etanol daun alpukat dengan konsentrasi $1 \% \mathrm{~b} / \mathrm{v}$ volume urinrata-rata sebesar $1,97 \mathrm{~mL}$, untuk ekstrak etanol daun alpukat dengan konsentrasi $2 \%$ b/vvolume urinrata-rata sebesar 2,2 mL, untuk ekstrak etanol daun alpukat dengan konsentrasi $3 \% \mathrm{~b} /$ vvolume urinrata-rata sebesar 4,3 $\mathrm{mL}$, sedangkan untuk pembanding furosemid $0,072 \% \mathrm{~b} / \mathrm{v}$ volume urinrata-rata sebesar $5,6 \mathrm{~mL}$. Volume urin setelah pemberian ekstrak daun alpukatyang paling efektif adalah konsentrasi $3 \% \mathrm{~b} / \mathrm{v}$ meskipun tidak seefektif pemberian suspensi furosemid $0,072 \% \mathrm{~b} / \mathrm{v}$.

Adapun kandungan kimia daun alpukat yang berkhasiat sebagai diuretik yaitu flavonoid yang berperan dalam meningkatkan pengeluaran urin (diuresis). Mekanisme kerja flavonoid sebagai diuretik yaitu dengan menghambat reabsorpsi $\mathrm{Na}^{+}, \mathrm{K}^{+}$dan Clsehingga menyebabkan peningkatan $\mathrm{Na}^{+}$dan air dalam tubulus. Dengan demikian, terjadi peningkatan volume air dalam tubulus sehingga terjadilah diuresis (Kumoro. A. C, 2015).

Hasil Analisis Varians (ANOVA) menunjukkan bahwa pemberian $\mathrm{Na} . \mathrm{CMC} 1 \% \mathrm{~b} / \mathrm{v}$ sebagai kontrol, ekstrak etanol daun alpukat $1 \% \mathrm{~b} / \mathrm{v}, 2 \% \mathrm{~b} / \mathrm{v}$ dan $3 \% \mathrm{~b} / \mathrm{v}$ sebagai zat uji dan suspensi furosemida $0,072 \% \mathrm{~b} / \mathrm{v}$ sebagai pembanding memberikan efek diuresis pada taraf $\alpha=0,05$ dan 0,01 dengan hasil pengujiannya bersifat sangat signifikan karena $35,6549^{* *}>3,48\left(\mathrm{Fh}>\mathrm{Ft}_{0,05}\right)$ dan $35,6549^{* *}>$ $5,99\left(\mathrm{Fh}>\mathrm{Ft}_{0,01}\right)$ yang berarti terdapat perbedaan rata-rata efek antara tiap perlakuan (Erlinda, Dwi. 2017).

Pada analisis data lanjutan menggunakan Uji Rentang Newman-Keuls untuk menentukan perbandingan setiap perlakuan sehingga ditemukan data yang bersifat non signifikan, maka diperoleh hasil bahwa terdapat perbedaan bermakna (signifikan) antara kelompok perlakuan ekstrak daun alpukat dan kelompok perbandingan suspensi furosemid $0,072 \% \mathrm{~b} / \mathrm{v}$, tetapi tidak terdapat perbedaan bermakna (non signifikan) pada pemberian Na.cmc $1 \% \mathrm{~b} / \mathrm{v}$ dengan ekstrak daun alpukat konsentrasi $1 \% \mathrm{~b} / \mathrm{v}$ dan konsentrasi $2 \% \mathrm{~b} / \mathrm{v}$ serta pemberian ekstrak daun alpukat konsentrasi $1 \% \mathrm{~b} / \mathrm{v}$ dengan ekstrak daun alpukat konsentrasi $2 \% \mathrm{~b} / \mathrm{v}$ (S. Elin. Y., dkk. 2015). 


\section{SIMPULAN DAN SARAN}

\section{Simpulan}

Berdasarkan hasil penelitian setelah dianalisis secara statistik dan pembahasan maka dapat disimpulkan bahwa Pemberian ekstrak daun alpukatpada konsentrasi $1 \% \mathrm{~b} / \mathrm{v}, 2 \% \mathrm{~b} / \mathrm{v}$ dan $3 \% \mathrm{~b} / \mathrm{v}$ memberikan efek diuretik tikus putih jantan dan Pemberian ekstrak daun alpukatpada konsentrasi3\% b/v menunjukan efek paling baik sebagai diuretik terhadap tikus putih, tetapi pemberian suspensi furosemid $0,072 \% \mathrm{~b} / \mathrm{v}$ masih memiliki efek yang lebih baik sebagai diuretik.

\section{Saran}

Berdasarkan simpulan diatas dapat di katakan bahwa sebaiknya untuk penelitian selanjutnyadilakukan uji efek farmakologi yang lain dari tanaman alpukat (Persea americanaMill.) dan dalam bentuk sediaan uji yang lain.

\section{DAFTAR PUSTAKA}

Akbar Budhi. 2010. Tumbuhan dengan Kandungan Senyawa Aktif yang Berpotensi sebagai Bahan Antifertilitas. Penerbit Adabia Press : Jakarta

Chandra, Andy, Hie Maria Inggrid, and Verawati Verawati. "Pengaruh $\mathrm{pH}$ dan Jenis Pelarut Pada Perolehan dan Karakterisasi Pati dari Biji Alpukat." Research Report-Engineering Science 2 (2013).

Depkes RI. 2014. Farmakope Indonesia, Edisi V. Penerbit Departemen Kesehatan Republik Indonesia : Jakarta

Erlinda, Dwi. 2017. "Efek Diuretik Ekstrak Etanol Daun Alpukat (Persea americana Mill.) Terhadap Histologi Lambung Tikus Putih Jantan (Rattus Norvegicus) Strain Wistar."

Febrianti, Novi, and Fajar Jaharia Sari. "Kadar Flavonoid Total Berbagai Jenis Buah Tropis Indonesia."2016

Gunawan, S.G.2016. Farmakologi dan terapi, Edisi VI. UI-Press : Jakarta

Guyton, A. C., dan Hall, J. E. 2002. Buku Ajar Fisiologi Kedokteran. Edisi ke9.Jakarta: EGC Kedokteran.

Hanani. E. 2014. Analisis Fitokimia. Penerbit Buku Kedokteran EGC : Jakarta

Karina Anna. 2012. Alpukat Khasiat dan Manfaat. Penerbit Stomata : Surabaya

Kumoro. A. C.2015. Teknologi Ekstraksi Senyawa Bahan Aktif dari Tanaman Obat. Penerbit Plantaxia : Yogyakarta

Latuconsina. N. H., dkk, 2014. Uji Efektivitas Diuretik Ekstrak Etanol Biji Salak (Salacca zalacca varietas zalacca (gaert.) Voss) pada Tikus Putih Jantan Galur Wistar (Rattus norvegicus). Jurnal Ilmiah Farmasi Vol.3 No.3 ISSN 2302-2493

Mutschler. E.2012.Dinamika Obat, Edisi Revisi. Penerbit Institut Tekhnologi Bandung : Bandung 
Avicenna : Journal of Health Research, Vol 4 No 1. Maret 2021 (111 - 117)

Meliana Novitasari, Kiki Puspitasary (Uji Efek Diuretik Ekstrak Daun Alpukat

(Persea Americana Mill) Pada tikus Putih (Rattus Norvegicus))

Sudradjat A. dan Aan S. 2017. Daya Hambat Rebusan Daun Alpukat (Persea americana Mill.) Terhadap pertumbuhan Bakteri Escherichia coli. Jurnal Sains Vol.7 No.13 ISSN 2087-0725

S. Elin. Y., dkk. 2015. Efek Diuretik Ekstrak Air Kelopak Bunga Rosela (Hibiscus sabdariffa Linn.) pada Tikus Wistar Jantan. Jurnal Farmasi Sains dan Terapan Vol.2 No.2

Tjay. T. H. dan Rahardjo. K.2010. Obat-obat Penting, Khasiat, Penggunaan dan Efek Sampingnya, Edisi VI. Jakarta

Yuniarti, T. 2008. Ensiklopedia Tanaman Obat Tradisional. MedPress : Yogyakarta 